\title{
Development of a Training Curriculum Structure to Improve ICT Competencies of Teachers in Primary Schools
}

\author{
Aah Ahmad Syahid ${ }^{\bowtie 1}$, Isrok'atun², \& Dadan Nugraha3 \\ 1,2,3 Primary School Teacher Education Program, Universitas Pendidikan Indonesia, Bandung, Indonesia \\ $\triangle$ syahid@upi.edu
}

\begin{abstract}
Possessing ICT skills for learning was a necessity for primary schools teachers in accordance with the requirements of current development and Education 4.0. This multi-year research had entered its third year in which it sought to discover information about the types of ICT training materials that were appropriate for the needs of teachers in primary schools and development of effectiveness of an ICT training curriculum structure. This research employed a descriptive survey design. The sample included 30 teachers in primary schools from 12 regions with different school characters in Sumedang Regency, West Java. The findings of this research showed an overview of a gap between teachers who had capabilities in utilizing ICT and teachers who needed to develop their capabilities in utilizing ICT through a practice. In attempting to mediate this gap, this research designed an ICT training curriculum structure that was appropriate for the needs of teachers in primary schools.
\end{abstract}

Keywords: ICT training, need analysis, training curriculum.

How to Cite: Syahid, A., Isrokatun, I., \& Nugraha, D. (2019). Development of a Training Curriculum Structure to Improve ICT Competencies of Teachers in Primary Schools. Mimbar Sekolah Dasar, 6(1), 21-31. doi:http://dx.doi.org/10.17509/mimbar-sd.v6il.13889.

INTRODUCTION Teachers are considered as the main movers in learning activities, therefore, their competencies are regulated in Law No. 14 of 2005 on Teachers and Lecturers in Chapter IV article 10 paragraph 1, and are explained in the Regulation of the Ministry of National Education No. 16 of 2007 . Hence, it is expected that all teachers should have good classroom management skills. Good classroom management will increase the effectiveness of learning activities and students' learning outcomes. Research by education experts in several developed countries such as Finland, Japan, and China showed that good classroom management would improve good learning outcomes of students in primary schools because the class is one of the places to develop attitudes, knowledge, and skills (Nagler, 2016; Yildiz, 2017). Nowadays, classroom is not limited to certain rooms. More than that, the presence of Information and Communication Technology (ICT) devices allows the interaction of students and teachers to occur without being narrowed by space and time.

Good classroom management at the primary school level in Indonesia is directed to integrate ICT tools in the learning activities. The use of ICT devices in learning activities in primary schools starts 
Aah Ahmad Syahid, Isrok'atun \& Dadan Nugraha, Development of a Training Curriculum Structure...

from the stages of planning, implementing, and evaluating (Sabanci, 2014).

In connection with the use of ICT for learning, a multi-year research showed that in 2015 only $13 \%$ of primary school teachers in rural areas in Sumedang District used ICT for learning activities. The problem of understanding and skills in utilizing ICTs did not only occur in primary school teachers in rural areas but also occurred in teachers in urban areas. In 2017, the results of research in urban areas in Sumedang Regency showed that only $39 \%$ of primary school teachers had accustomed to using ICT for learning. Problems in the use of ICTs for learning activities were allegedly and indeed become a problem for teachers' working culture. This problem was not merely caused by the lack of the teacher's skills to use ICT, but also not accustomed to carry out learning using ICT.

Having competency in implementing ICTbased learning has become a necessity for primary school teachers in Indonesia. Competency regarding the use of ICT for learning activities has been regulated in the Regulation of the Ministry of National Education No. 16 of 2007 in the teacher's pedagogical competence. In international scope, in 2011, UNESCO officially published a comprehensive ICT competency framework for teachers that became a guideline for ICT competency standards for each teacher. This framework is also used by the government and education observers to develop teachers' skills. There are several subcompetencies that are the targets of UNESCO in developing teacher competencies, including; (1) aspects of ICT understanding in education; (2) aspects of ICT for curriculum and assessment; (3) aspects of ICT for pedagogical practices in schools; (4) aspects of ICT for learning; (5) aspects of ICT for organization, and (6) aspects of ICT for teacher self-development (UNESCO, $2011)$.

After analyzing a number of studies on the use of ICTs for learning in primary schools, it is found that several studies showed the similar agreement on the need of teachers' good ICT skills for learning. Uluyol \& Şahin (2016) examined 101 primary school teachers in Turkey. The results showed that there was a need to increase motivation to use ICT for teachers because primary school students in parts of Europe and Asia needed ICT-based media support for learning. Therefore, ICT training for teachers is considered as an effective solution to improve the competence (Uluyol \& Sahin, 2016). In line with that, another research conducted by Law et al. (2005) in Finland and Hong Kong, which were considered successful countries in terms of education, presented data that ICTs were the main supporters in the modern and effective educational process. Successful learning cannot be separated from the presence of digital technology devices and media. Hence, successful teachers are teachers who can 
Use ICT for learning. Finland, a European country, is a country utilized $63 \%$ ICT components and internet connection in learning implementation in primary schools, and this percentage is believed to increase. Whereas, Hong Kong, an Asian country, had a lower percentage. However, as a developed country, they have positioned ICT competencies as teachers' most important competencies in primary schools (Law et al., 2005).

It is believed that research on the importance of ICT competencies in primary school learning needs to be continued. This should not merely look at the percentage of ICT competencies held by teachers but also directed at developing an effective solution to improve ICT skills for primary school teachers. The development of ICT training curriculum for primary school teachers should be carried out through training needs analysis. Needs analysis in curriculum development is the most important activity, so effective training can be prepared and the training activities are not wrongly targeted (Kresnanda, 2018).

This research has developed a structure of an ICT training curriculum for primary school teachers, to improve the skills of primary school teachers. It has been adjusted through a gap analysis between the abilities that have been possessed by the teacher and the abilities that must be possessed by the teacher.

\section{METHODS}

This research employed a descriptive survey method. The survey method in this research led to data collection in the form of opinions written in questionnaires and instruments for analyzing the needs of a number of populations (Gay\& Diehl, 1992). Survey method was chosen because this research involved large population and this method is considered more effective in obtaining data from 30 primary school teachers in 12 sub-districts in Sumedang, West Java, Indonesia. The following Table 1 presents the respondents characteristics.

Table 1. Characteristics of Research Respondents.

\begin{tabular}{cccccccccc}
\hline & Sex & \multicolumn{10}{c}{ Age } \\
\hline Male & Female & Total & $<25$ & $25-30$ & $31-35$ & $36-40$ & $41-45$ & $>45$ & Total \\
12 & 18 & 30 & 3 & 6 & 5 & 6 & 5 & 5 & 30 \\
$40 \%$ & $60 \%$ & $100 \%$ & $10 \%$ & $20 \%$ & $16.67 \%$ & $20 \%$ & $16.67 \%$ & $16.67 \%$ & $100 \%$ \\
\hline
\end{tabular}

Data collection was done through questionnaire based on the aspects of needs analysis for training planning, which was developed by Wentling (1994, pp. 8792). The needs analysis worksheet consists of (1) questionnaire analysis of teacher work, (2) questionnaire analysis of teacher assignments, and (3) gap identification sheet. In addition to questionnaire instruments, interviews and observations were also used to test and analyze the results of the respondents' answers to the questionnaire.

The data were collected in six months in the following procedure: . First, collecting teachers' task analysis in utilizing ICT for 
Aah Ahmad Syahid, Isrok'atun \& Dadan Nugraha, Development of a Training Curriculum Structure...

learning, in which the research instruments were developed based on the UNESCO ICT Framework for Teacher guidelines; Second, collecting data to analyze the details of the teacher's task in utilizing ICT for learning in primary school; Third, determining the skills that had been and had not been mastered by the respondents.

\section{RESULTS}

\section{Analysis of ICT Training Material Requirements}

The development of an ideal training curriculum always begins with a process of needs analysis. The needs analysis in this research aims at finding the gap between the skill to use ICT that had been and had not been mastered by the teachers. Therefore, the determination of good training material was in accordance with the training participants' needs because the training would be meaningful to the participants if it was in accordance with what they needed. This is similar to what was conveyed by Vatanartiran (2015) that needs analysis is an introduction to the success of training, which lead the direction of training planning. Moreover, ICT skills training for teachers must be in accordance with the conditions of the teacher where they are not in the same age (Ghavifekr \& Rosdy, 2015).

Needs analysis in this research was conducted by processing questionnaire based on the UNESCO's teachers' ICT skills. The result of data processing of teacher competency gap is presented in Table 2 below.

Table 2. Teacher Competency Gap in ICT Utilization.

\section{ICT Competency Framework for Teachers}

NT* $^{*}$

$\mathrm{DNT}^{* *}$ 


\begin{tabular}{lcc}
\hline \multicolumn{1}{c}{ ICT Competency Framework for Teachers } & NT $^{*}$ & DNT** $^{* *}$ \\
\hline c. Utilization of ICT in the participation and contribution of discussion forums & $\sqrt{ }$ \\
d. Utilization of ICT for research facilities & \\
Information: & \\
$* * \quad \mathrm{NT}=$ Needs Training & \\
Source: research data calculation results & DNT = Does not need training
\end{tabular}

Table 2 shows that there are competencies that did not need to be trained because they were assumed to be mastered by the teacher, and vice versa. After obtaining list of competencies to be trained, then the competency standards that had to be owned by the teacher in ICT training were prepared. The preparation was based on the types of determined by the respondents, so that the determination of the competency standards could be ascertained as the competencies that would be possessed by curriculum users (Taylor, 2003). Based on the obtained results of competency gap analysis, following (Table 3 ) is the ICT training competency standards for primary needs and gaps that had been school.

Table 3. Competency Standards.

\begin{tabular}{ll}
\hline No. & Competency Standards \\
\hline 1. & Participants are able to understand well the latest government policies regarding the use of ICT \\
in education \\
2. Participants are able to use ICT for making learning devices \\
3. Participants are able to practice the use of the latest technology for learning in primary schools \\
4. Participants are able to use ICT for teacher professional development \\
\hline Source: research data calculation results.
\end{tabular}

The process of developing material on the structure of the curriculum was prepared by considering the above four competency standards. These competency standards were supported by several training materials, so that each competency will consist of several training materials that will be trained to participants (Zais, 1976).
Based on the discussions results with several experts through the Forum Group Discussion (FGD) represented by two curriculum development expert lecturers and two prospective curriculum users, the details of ICT training materials for primary school teachers is presented in the following Table 4.

Table 4. Details of ICT Training Materials.

\section{No. Competency Standards}

Training Materials

\footnotetext{
1. Participants are able to understand well the latest government policies regarding the use of ICT in education

1. The utilization of ICT for education and learning

2. The Concept of Information Literacy

3. The Concept of Media Literacy

4. The Concept of Digital Literacy

2. Participants are able to use ICT for making learning devices primary

5. ICT for preparing Lesson Plans (RPP, Rencana Pelaksanaan Pembelajaran)
} 


\begin{tabular}{|c|c|c|}
\hline No. & Competency Standards & Training Materials \\
\hline & & $\begin{array}{l}\text { 6. ICT for developing learning materials } \\
\text { 7. ICT for making learning media } \\
\text { 8. The utilization of ICT for the } \\
\text { implementation of learning in primary } \\
\text { schools }\end{array}$ \\
\hline 3. & $\begin{array}{l}\text { Participants are able to practice the use of } \\
\text { the latest technology for learning in schools }\end{array}$ & $\begin{array}{l}\text { 9. Internet as a learning resource } \\
\text { 10. Learning using audiovisual media } \\
\text { 11. Learning using multimedia }\end{array}$ \\
\hline 4. & $\begin{array}{l}\text { Participants are able to use ICT for teacher } \\
\text { professional development }\end{array}$ & $\begin{array}{l}\text { 12. Social media for educational } \\
\text { communication (with students, parents, } \\
\text { and teacher forums) }\end{array}$ \\
\hline
\end{tabular}

Source: research data calculation results.

There were 12 training materials compiled in the training curriculum for teacher to master ICT competencies, as follows:

Material 1: The Utilization of ICT for Education and Learning

The government policies regarding the use of ICT in education and learning will be discussed in general. It will require 2 hours training to explain ICT frameworks and implementation that can be integrated into learning by teachers at the primary school level.

Material 2: Information Literacy in Primary Schools

The media development that facilitates acceptance by society requires knowledge to filter out information that can be received and information to be ignored. Information literacy that will be discussed in this material refers to how to collect important information for students and educators that can be used as learning material in the classroom. This information literacy material will require 2 hours training presented in the form of theory or lecture.
Material 3: Media Literacy in Primary Schools

Basically, learning activities can present any media as an intermediary for teachers with students to facilitate the achievement of learning objectives. Nowadays, the rapid developments of media (visual, audio, audiovisual) that can be used in learning require the teacher to be more creative in choosing the right one to be brought into the classroom. This material will help participants to be more literate about the right learning media at the primary school level. This material will require 2 hours training presented in the form of theory or lecture.

Material 4: Digital Literacy in Primary Schools

The developing digital media this time requires teachers to be digitally-literate because the learning media used today are more directed at digitalization. In addition to learning activities, teacher administration and teacher coordination with other teachers or with other schools should also use digital media. This material will require 2 hours training presented in the form of theory or lecture. 
Material 5: ICT for Preparing Lesson Plans (RPP)

This material will teach the use of a word processing program to compile a good and correct lesson plan. This material will be presented in the form theory and practice that will require 3 hours training.

Material 6: ICT for the Development of Learning Materials

Planning learning materials, searching through search engine programs on the internet, printing, and making the flow of explanation will be discussed in this material. This material will be presented in the form of theory and practice and will require 3 hours training.

\section{Material 7: ICT for Making Learning Media}

After lesson plans and material are arranged, then ICT-based interesting learning media can be made by utilizing ICT devices and the Internet. This material will be presented in the form of theory and practice and require 6 hours training.

Material 8: The Utilization of ICT for Learning Implementation in Primary Schools

It is necessary to do ICT-based practice and learning simulation. This material will discuss how to implement ICT-based learning at the primary school level and will be presented in the form of theory and practice. This material will require 3 hours training.

Material 9: Learning Using Audiovisual Media

Furthermore, it is also necessary to practice simulation for learning using audiovisual media for learning at the primary school level. The theory and practice of this material will require 4 hours training.

Material 10: Learning Using Multimedia

In addition to audiovisual media, interactive multimedia is also required to be mastered. In this material, the theory and practice of using multimedia for learning will be presented in 4 hours training.

Material 11: Internet as a Learning Resource

As additional material, the internet will be discussed as a learning resource. In this material, participants will be led to understand the internet as an information center that can be developed for learning in primary schools. This material will be presented in the form of theory that requires 2 hours training.

Material 12: Social Media for Educational Communication

Social media presence eases teachers' communication with students, parents and other teachers. This material will discuss the selection of appropriate social media and how it will be used for communication activities in education. This material will be presented in the form of theory and will require 2 hours training.

\section{Curriculum Structure of ICT Training}

The ICT training curriculum was structured based on the teachers needs that had been analyzed to obtain the competency and material standards needed by the 
Aah Ahmad Syahid, Isrok'atun \& Dadan Nugraha, Development of a Training Curriculum Structure...

training participants. The next stage of training curriculum development is to design the structure of the curriculum and complete it with information on the weight or duration of the training activities in each material so that it can be used as a guideline and reference for the participants (Print, 1993).

The structural design of the training curriculum was also compiled based on the results of scientific meetings with curriculum experts (lecturers) and prospective curriculum users (teachers) in the Focus Group Discussion (FGD) forum. The curriculum structure was made in three categories: basic material, core material, and supporting material. Furthermore, in the structural design of the ICT training curriculum, theory or practice description was also given to each material and was adjusted to the characteristics of the material.
The right strategy for implementing a training curriculum is to have a mix of theory and practice because presenting training to teachers as participants means that the learning system to be implemented must carry the principle of andragogy (Friedman, 1985). Another strategy that will be developed in general is the presence of several training activities as presented by Print (1993, pp. 127) in his book that there must be at least lectures, question and answer, discussion, group work, and practice in adult learning activities.

The following is the structure of the ICT training curriculum for primary school teachers who are also being prepared for publication on Journal of Physics: Conference Series (A A Syahid, in Press).

Table 5. Curriculum Structure Design of ICT Training.

\begin{tabular}{|c|c|c|c|}
\hline \multirow{2}{*}{ MATERIALS } & \multicolumn{3}{|c|}{ TIME } \\
\hline & $\mathbf{T}$ & $\mathbf{P}$ & TOTAL \\
\hline \multicolumn{4}{|l|}{ Group A: Basic Material } \\
\hline a. The utilization of ICT for education and learning & 2 & - & $2 \mathrm{Hrs}$ \\
\hline \multicolumn{4}{|l|}{ Group B: Core Materials } \\
\hline a. Information literacy in primary schools & 2 & - & $2 \mathrm{Hrs}$ \\
\hline b. Media literacy in primary schools & 2 & - & $2 \mathrm{Hrs}$ \\
\hline c. Digital literacy in primary schools & 2 & - & $2 \mathrm{Hrs}$ \\
\hline d. ICT for preparing lesson plans (RPP) & 1 & 2 & $3 \mathrm{Hrs}$ \\
\hline e. ICT for developing learning materials & 1 & 2 & $3 \mathrm{Hrs}$ \\
\hline f. ICT for making learning media & 1 & 5 & $6 \mathrm{Hrs}$ \\
\hline g. The utilization of ICT for learning implementation in primary schools & 1 & 2 & $3 \mathrm{Hrs}$ \\
\hline Learning using audiovisual media & 1 & 3 & $4 \mathrm{Hrs}$ \\
\hline i. Learning using multimedia & 1 & 3 & $4 \mathrm{Hrs}$ \\
\hline \multicolumn{4}{|l|}{ Group C: Supporting Materials } \\
\hline a. Internet as a learning resource & 2 & - & $2 \mathrm{Hrs}$ \\
\hline b. Social media for educational communication & 2 & - & $2 \mathrm{Hrs}$ \\
\hline Total training hours & 18 & 17 & $35 \mathrm{Hrs}$ \\
\hline
\end{tabular}

Source: research data calculation results. 
The material group on the design of the training curriculum structure has been divided into three categories:

\section{Basic Material Group}

This will contain materials about government policies and basic theories about the use of ICT for education and learning, especially at the primary school level. It will focus on the utilization of ICT for education and learning.

\section{Core Material Group}

This will contain the main topics to be learned in the training, which are related to the use of ICT for teachers ranging from planning the lesson to the implementation of learning. The core material consists of nine subjects: (1) information literacy in primary schools, (2) media literacy in primary schools, (3) digital literacy in primary schools, (4) ICT for preparing lesson plans (RPP), (5) ICT for developing learning materials, (6) ICT for making learning media, (7) The utilization of ICT for learning implementation in primary schools, (8) learning using audiovisual media, and (9) learning using multimedia.

\section{Supporting Material Group}

This is additional material that will equip participants with additional knowledge related to the subject matter of the training. There will be two training subjects, namely: (1) internet as a source of learning, and (2) social media for educational communication.

All of the materials will be carried out with two types of training activities: lectures on the theory and practice. In its implementation, it will begin with lecture, but not all of them will need practice. The practice will be on materials that require direct contact with the skills of using ICT, including ICT for preparing lesson plans, ICT for developing learning materials, making ICT-based media, and teaching simulation using ICT devices.

\section{DISCUSSION}

This development of an ICT training curriculum was an effort to improve teacher competence, especially pedagogical competencies in effective classroom management practices in primary schools. Each type of training was expected to be able to provide maximum skill development for the participants. Therefore, the planned training activities were analyzed as deep as possible so that they will be effective and in accordance with the needs of the participants. The activity of designing effective training began with a needs analysis, hence, the most suitable materials on the competencies targeted to be mastered by participants were measured. This procedure had become a standard step in developing training curriculum activities because the curriculum programs must be in the forms of ready-to-use products and in accordance with the needs of participants (Wentling, 1994).

This research contributes to the scientific product of research in the form of structural design of training curriculum for 
Aah Ahmad Syahid, Isrok'atun \& Dadan Nugraha, Development of a Training Curriculum Structure...

primary school teachers. The arranged material arereferred to the UNESCO'S ICT Framework for Teacher, which also served as a guideline for the development of ICT competencies in various developed countries. Research in other developing countries conducted by Marcial \& Rama (2015) from Silliman University Philippines also employed the UNESCO ICT Framework for Teacher as the basis of his research on teacher level in mastering ICT competencies, which only measured the level of ICT skills in teachers. In contrast, this research actually employed the ICT competency framework of UNESCO as a reference in developing training materials.

In general, there are six aspects of ICT competence from the UNESCO ICT Framework for Teacher. However, in this research, the six aspects were modified and combined with other aspects because they had the same character as follows: (1) ICT in education. This aspect included the teacher's understanding of government policies in the utilization of ICT in the field of education. It was expected that teachers were able to translate these policies to be implemented in effective and conducive learning activities. (2) Pedagogy, Curriculum, and Assessment. This aspect included the teachers' skills in the utilization of ICT in planning, preparation of learning strategies, media development, curriculum development, management of the learning environment, assessment, and utilization of ICTs for students with special needs. (3) ICT Tools.
This aspect included the competence of teachers in the utilization of ICT equipment, both used for multimedia, internet, audiovisual media, and ICT for administrative learning needs. (4) Organization and Administration. This aspect was related to the teachers' skill to integrate ICTs for learning administration management, selfdevelopment, and as a means of developing teacher professionalism.

The positive implications of the formation of an ICT training curriculum will provide an effective design of training activities. The next activity that can be done after the formation of this curriculum is to prepare other administrative tools, such as training syllabus, training event unit (SAP, Satuan Acara Pelatihan), training modules, training media, and training evaluation instruments.

\section{CONCLUSIONS}

Based on the results of the needs analysis and development of the curriculum structure, it can be concluded that ICT competencies for primary school teachers for learning activities needed to be developed. The most effective development will be through training according to the needs of the teacher. The curriculum structure compiled in this research is considered suitable to improve ICT skills for primary school teachers because it was developed based on teacher needs through in-depth analysis and data processing and discussions with curriculum development experts. 


\section{REFERENCES}

A A Syahid, I. I. (in Press). ICT Training Curriculum To Develop Primary School Teachers' Pedagogy. Journal of Physics: Conference Series.

Friedman, P. A. (1985). Training Strategies From Start to Finish. New Jersey: Prantice-Hall International Inc.

Gay, L.R. \& Diehl, P.L. (1992). Research Methods for Business and Management. New York: MacMilan Publishing Company.

Ghavifekr, S., Rosdy, W.A.W. (2015). Teaching and Learning with Technology: Effectiveness of ICT Integration in Schools. International Journal of Research in Education and Science (IJRES), 1 (2), 175-191.

Kresnanda, S. (2018). Why Training Fails? And What To Do About It. Malang: Litera Mediatama.

Law, N., Kankaanranta, M., \& Chow, A. (2005). TECHNOLOGY-SUPPORTED EDUCATIONAL INNOVATIONS IN FINLAND AND HONG KONG: A TALE OF TWO SYSTEMS. Human Technology: An Interdisciplinary Journal on Humans in ICT Environments, 176-201.

Marcial, D.E., Rama, P.A. (2015). ICT Competency Level of Teacher Education Professionals in the Central Visayas Region, Philippines. Asia Pacific Journal of Multidisciplinary Research, 3(5), 29-38. Retrieved from www.apjmr.com

Nagler, K. S. (2016). Effective ClassroomManagement \& Positive Teaching. English Language Teaching, 9(4), 163172.

Oliva, P. F. (2013). Developing the Curriculum (Eighth Edition). Boston: Pearson.

Print, M. (1993). Curriculum Development and Design (second edition). Australia: Allenand Uuwin.

Sabanci, A. (2014). The Effect of ICT Usage on the Classroom Management: A Case Study in Language Teaching.
International Review of Social Sciences and Humanities, 7(1), 232245.

Taba, H. (1962). Curriculum Development. New York: Harcourt, Brace \& World, Inc.

Taylor, P. (2003). How To Design a Training Course . London: Cromwell Press Ltd.

Uluyol, Ç. Şahin, SamiS. (2016). Elementary school teachers' ICT use in the classroom and their. British Journal of Educational Technology, 47(1), 65-75. doi:10.1111/bjet.12220

UNESCO. (2011). UNESCO ICT Framework For Teachers. France: United Nations Educational, Scientific and Cultural Organization.

Vatanartiran, S., Karaeniz, S.(2015). A Needs Analysis for Technology Integration Plan: Challenges and Needs of Teachers. Contemporary Educational Technology, 6(3), 206-220.

Wentling, L. (1994). Planning for Effective Training. Romee: W.D Maalouf Officer in-Change.

Yildiz, N. G. (2017). Classroom Management and Student Achievement: A Study on Five Elementary. AJESI - Anadolu Journal of Educational Sciences International, 7(1), 155-183.

Zais, R. (1976). Curriculum: Principles and Foundations. New York: Harper \& Row Publisher. 